\title{
Meio século de desigualdades no Brasil
}

Marta Arretche (ed.). Trajetórias da desigualdade: como o Brasil mudou nos últimos 50 anos. 1. ed. São Paulo, Editora da Unesp, 2015. 489 páginas.

\section{Marcelo Medeiros}

Há anos não se publicava um livro tão abrangente sobre a desigualdade no Brasil, ou, mais exatamente, sobre as desigualdades, pois Trajetórias $d a$ desigualdade: como o Brasil mudou nos últimos 50 anos trata de desníveis em participação política, condições habitacionais, renda, educação, saúde e saneamento ao longo de meio século.

A combinação de temas é o primeiro grande mérito do livro; o segundo, a perspectiva histórica abrangente de cinco décadas. $\mathrm{O}$ enfoque recai sobre as trajetórias e não sobre as flutuações de curto prazo. Interessam as grandes tendências e os fatores que as impulsionam. Nesse sentido, os detalhes assumem protagonismo apenas quando marcam inflexões nessas tendências. Sinal disso é o cronômetro usado quando se avaliam políticas públicas: o tempo se mede por fases políticas, não pelo nome dos governantes.

Trajetórias da desigualdade é uma coletânea de quatorze estudos, escritos por 28 autores de várias instituições e coordenados por Marta Arretche. Para cobrir cinquenta anos de história esses estudos lançam mão de uma profusão de estatísticas de registros eleitorais, censos e pesquisas domiciliares complementadas com alguns dados de outras fontes. Denso e longo, o livro beira as quinhentas páginas. Como sempre ocorre com coletâneas, o conteúdo e a linguagem dos capítulos variam, o que certamente diversifica o interesse do leitor. Alguns são demasiadamente técnicos para um público amplo; outros complicam o que poderia ser apresentado de forma muito simples; uns poucos dão atenção excessiva a descriçôes de importância secundária, que atrasam a compreensão dos argumentos. Ou seja, a coletânea peca os pecados veniais quase inevitáveis desse tipo de livro. Pecados capitais não há. Regra geral, é muito boa qualidade dos estudos.

Nos estudos sobre desigualdade, fatos e valores não se separam. Até na aparente isenção das estatís- 
ticas a mensuração da desigualdade reflete, implícita ou explicitamente, juízos de valor. Guia o livro uma noção igualitarista de justiça. Pode até haver alguma divergência sobre como obter a igualdade, quanta igualdade obter ou sobre quais são as desigualdades mais importantes, mas não há dúvida de que igualdade é um objetivo a se alcançar nas preocupaçóes dos principais capítulos. Trata-se, portanto, de um livro engajado por seus valores. Porém, benefício adicional da perspectiva histórica, ficam de lado as pequenas paixões: nem triunfalismo nem catastrofismo têm espaço no texto.

É difícil sintetizar o que há por trás de tantos estudos, autores e temas. Mas há uma ideia que costura os capítulos: nos últimos cinquenta anos a igualdade no Brasil foi obtida predominantemente por inclusão, não por redistribuição. Isso merece esclarecimentos. Há várias maneiras de se promover a igualdade por meio de políticas públicas, que podem ser agrupadas em duas grandes categorias, igualdade por inclusão e igualdade por redistribuição. A classificação encerra certo artificialismo, mas é útil para entender o eixo no qual giram as ideias do livro.

Políticas de igualdade por inclusão são aquelas que reconhecem certos avanços de uma parte da população, definindo-os como um marco absoluto, e buscam recuperar o atraso do restante das pessoas em relação a eles. São desenhadas para usar os recursos fiscais disponíveis de modo a dar aos que têm menos aquilo que se considera básico ou essencial e já foi garantido a outros. $\mathrm{O}$ universalismo ou, mais exatamente, um tipo minimalista de universalismo, é o princípio de justiça que norteia a igualdade por inclusão.

Políticas de igualdade por redistribuição trabalham com marcos relativos. Identificam diferenças e se empenham em reduzi-las, retirando dos que têm mais para redistribuir aos que têm menos. São desenhadas para aumentar a disponibilidade de recursos fiscais para fins redistributivos e realocar vantagens dos que têm mais aos que têm menos. A igualdade por redistribuição é guiada por princípios de equidade.

Há artificialismo na classificação porque a recuperação do atraso absoluto também pode ser - e às vezes é - obtida por redistribuição. Além disso, boa parte da alocação de recursos para os que têm menos é também uma forma de redistribuição. Seria possível buscar fronteiras mais rigorosas, mas o que importa aqui é a tônica geral das intençôes presentes no desenho das políticas, pois isso é o que mais ajuda a entender as trajetórias das desigualdades no Brasil neste meio século: políticas redistributivas são mais impacientes e ambiciosas no grau de igualdade que querem alcançar.

É recorrente no livro o fato de a história brasileira ser marcada por uma igualdade por inclusão. Ou seja, a redução da desigualdade por meio de políticas, quando ocorreu, foi determinada por medidas inclusivas em políticas que não foram desenhadas com propósitos explicitamente distributivos.

Mas nem toda queda na desigualdade ocorreu devido à ação do Estado. Movimentos importantes na direção da igualdade ocorreram independentemente da ação estatal direta. É o caso, por exemplo, da redução das diferenças de gênero. Aliás, alguns resultados sugerem que a desigualdade caiu apesar da ação do Estado e não graças a ela. A própria ideia de igualdade por inclusão, em que o Estado cria benefícios para um grupo privilegiado e, em seguida, reduz obstáculos de incorporação para incluir a massa da população nesses benefícios, indica que há ações do Estado que, ao menos inicialmente, podem aumentar em vez de reduzir a desigualdade.

Os diversos capítulos apontam que políticas foram desenhadas com propósitos diferentes para atender a interesses de grupos distintos, e, evidentemente, algumas delas resultaram em redução da desigualdade, outras, em aumento. Uma imagem talvez exagerada, mas certamente clara, expressa a ambiguidade da ação pública: com uma mão o Estado afaga os pobres, com a outra acaricia os ricos. Há muita gente entre pobres e ricos para que uma imagem dessas dispense ressalvas, mas a ideia básica está aí.

Se o Estado tende quase a um dualismo, a pergunta central que imediatamente surge é sobre o que move políticas na direção da igualdade. A primeira resposta que vem à cabeça é "democracia”. De fato, nos períodos democráticos da história brasileira a desigualdade tendeu a cair; durante as ditaduras, subiu ou, quando muito, caiu mais lentamente.

Todavia, pelo menos dois capítulos mostram que a mera participação eleitoral não gera igualdade automaticamente. A competição política cria 
condições gerais favoráveis à adoção de medidas igualitárias, mas são mudanças efetivas no desenho das políticas públicas que levam à igualdade. $\mathrm{Ou}$ seja, a redução da desigualdade depende mais de condições específicas do que gerais. Sua conformação não resulta apenas da possibilidade de escolhas eleitorais, mas de uma democracia em sentido mais profundo, que afeta camadas menos evidentes das ações do Estado. Não surpreende, portanto, que políticas tenham efeitos independentes e muitas vezes contraditórios sobre a desigualdade. Esses efeitos decorrem da forma como as linhas gerais de política foram efetivamente implementadas.

Trajetórias da desigualdade conta uma história de meio século de desigualdades no Brasil com rigor e detalhe. Trata de várias dimensões do bem viver e busca unificar ideias implícitas em uma grande quantidade de estudos. Combina décadas de estatísticas com análise institucional. É um livro que merece as boas-vindas de quem acredita que para se entender a sociedade brasileira é preciso saber o que faz o país tão desigual.

\section{MARCELO MEDEIROS, sociólogo, é pesquisador do Instituto de Pesquisa Econômica Aplicada (Ipea) e professor na Universidade de Brasília (UnB). E-mail: mclmdr@unb.br.}

DOI: http//dx.doi.org/10.17666/3190175-177/2016 